\title{
MACRO- AND MICROMORPHOLOGY OF THE STEM AND LEAF OF CALLIANDRA HAEMATOCEPHALA (HASSK.) CULTIVATED IN EGYPT
}

\author{
N. A. El-Emary, M. A. Makboul, M. A. Abdel-Hafiz, M. M. Magdy \\ Department of Pharmacognosy, Faculty of Pharmacy, Assiut University, Assiut, Egypt

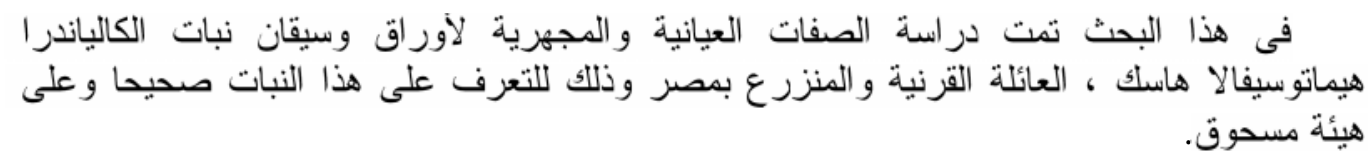

The detailed macro- and micromorphological characters of the stem and leaf of Calliandra haematocephala (Hassk.) [C. inaequilatera (Rusby)] cultivated in Egypt have been studied in order to find out the diagnostic features which can help in the identification of these parts in both entire and powdered forms.

\section{INTRODUCTION}

Calliandra haematocephala (Hassk.); [C. inaequilatera (Rusby)] family Fabaceae (Pea or Legume), ${ }^{1-4}$ is an evergreen shrub or small trees widely distributed in tropics ${ }^{5,6}$, native to tropical America, Bolivia, cultivated in different regions as Malesia, South Florida, Australia and recently introduced to Egypt. ${ }^{4}$

The genus Calliandra has many folk uses; the aqueous extract of the branches of $C$. anomala was used as antimalarial and antifebrile agent in Mexico, ${ }^{7}$ dried leaves of $C$. portoricensis snuffed to relieve headache; the root mixed with ginger and water as enema to treat lumbago and constipation or mixed with pepper to treat gonorrhoea, this species is reported to have abortive properties. ${ }^{8}$ The leaves and whole plant are used for treatment of fever, diarrhea and infantile convulsions. ${ }^{9}$ Pharmacological studies have been done on the active principles of the leaf extract which may be responsible for the antiulcer and anticholinergic effects. ${ }^{10}$ The aqueous extract of both root and stem were studied for their anticonvulsant activity. ${ }^{11}$ Antimicrobial activity of the leaf extracts have been studied. ${ }^{10}$ The decoction of $C$. californica (Benth), locally known as "Tabardillo", is used in Baja California to treat kidney ache, cystitis, urethritis and gall stones, also the plant extract has antimicrobial activity and can inhibit prostaglandin synthetase activity. ${ }^{12}$

Generally, the biological studies on genus Calliandra stated that it has antimicrobial, ${ }^{14,15}$ insecticidal, ${ }^{16,17} \quad$ molluscicidal, ${ }^{18}$ antiulcerogenic, anticholinergic ${ }^{10}$ and anticonvulsant activities. ${ }^{11}$ As for Calliandra haematocephala, the decoction of the flower is said to be blood purifier and tonic. ${ }^{13}$ The fungitoxic effect of pipecolic acid ${ }^{19,20}$ derivatives isolated from this species was studied.

This work describes the macro- and micromorphological characters of stem and leaf of Calliandra haematocephala (Hassk.).

\section{EXPERIMENTAL}

Calliandra haematocephala (Hassk.) (Figs. 1,2) is an evergreen erect deciduous shrub 1-3 meters height with spreading pendulous branches, form a dense round head. It carries alternate compound, bipinnate leaves that fold together in cloudy weather and in darkness. ${ }^{21}$ Flowers are watermelon pink with numerous silky stamens, white flowering form is also available., ${ }^{4,5}$ They are sessile and arranged on small dense flower head (capitulum). ${ }^{22}$ The flowers bloom from October to March. ${ }^{4}$ The fruit is a legume. 


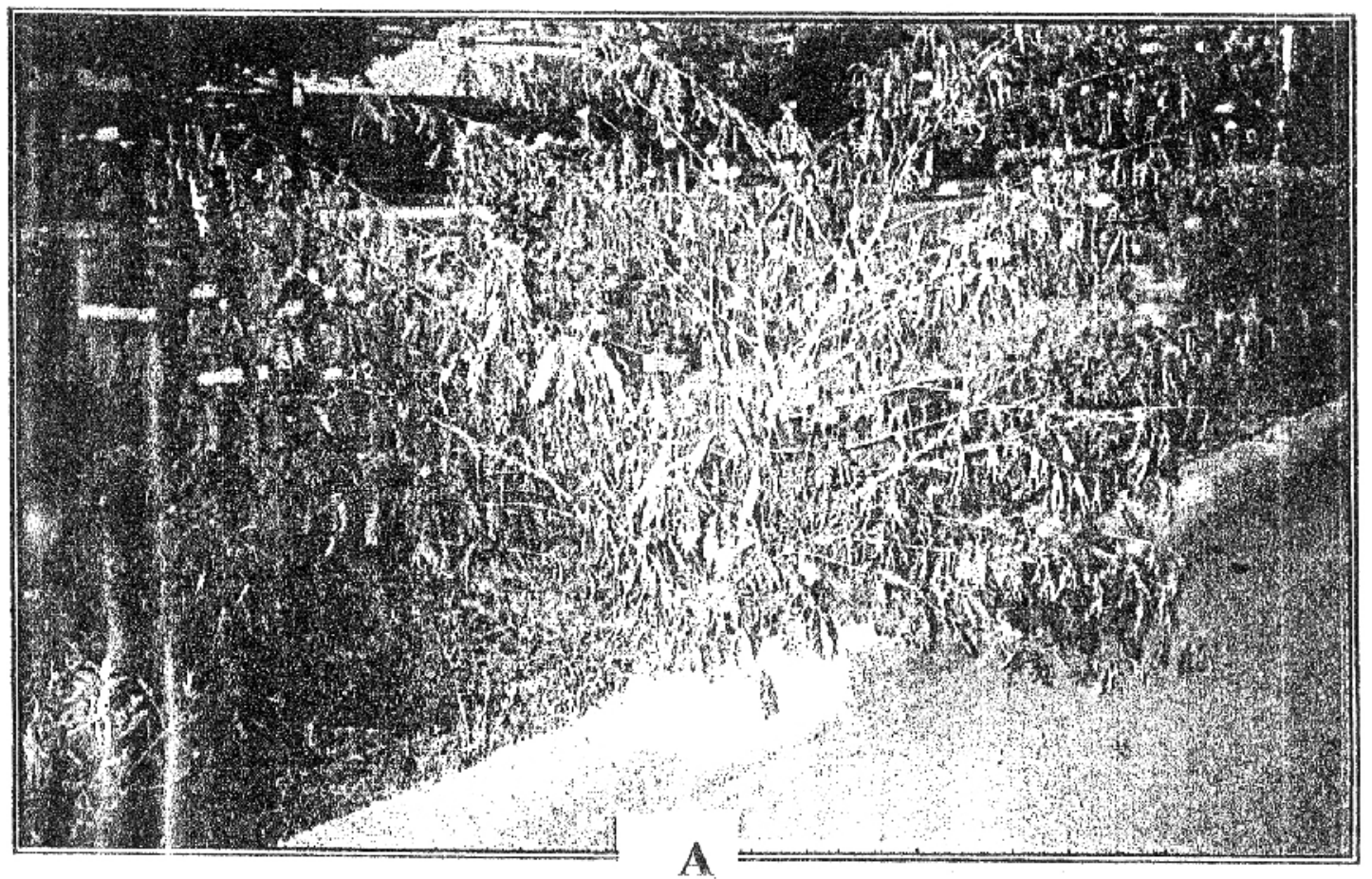

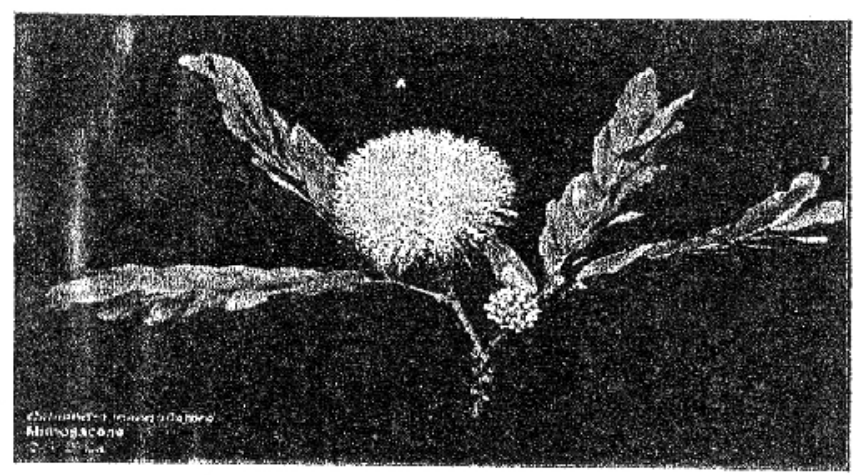

13

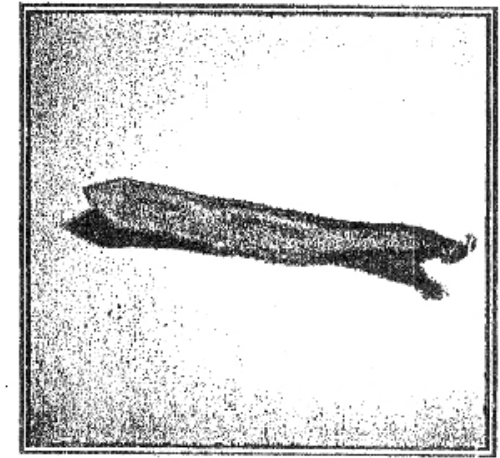

4

Fig. 1: A- Photo of the plant

x 0.1

B- Photo of the inflorescence with stipules

x 0.25

C- Photo of the fruit

x 0.7 


\section{Plant material}

The plant was cultivated in the experimental station of Faculty of Agriculture, Assiut University, Assiut, Egypt and was kindly identified by Prof. Dr. Naeem Esa, Head of Department of Horticulture, Faculty of Agriculture, Assiut University, Assiut, Egypt. Fresh samples of the plant were collectd by authors in the period from November 2001 to October 2002. The samples were gathered before and during flowering and fruiting stages. Fresh stems and leaves were preserved in a mixture of alcohol (70\%) - glycerin-water (1:1:1). The different plant organs viz. stems and leaves were air dried and reduced to fine powder.

\section{1- The Stem}

\section{Macromorphology of the stem}

The main trunk of the plant (Fig. 1A) is hard, woody, erect, cylindrical, monopodially branched, reaching about 1-3 meters height and 20-22 cm in diameters. It carries numerous cylindrical alternate spiny branches with swollen nodes and short internodes measuring $1-6 \mathrm{~cm}$ long.

The young branches (Fig. 2A) have smooth surface, green colour while the very old ones are brown, rough and covered with brownish cork, at the basal part of the trunk.

The surface of the moderately old stem (Fig. 2C) is brownish green in colour and longitudinally wrinkled. The stem breaks with a fibrous fracture. It has a faint odour and astringent taste.

\section{Micromorphology of the stem}

A transverse section in young stem (Fig. $3 \mathrm{~A}$ ) is more or less rounded in outline. It is formed of an epidermis carrying non-glandular trichomes. The outer zone of the cortex is narrow and formed of collenchymatous cells followed internally by wide zone of parenchymatous cells. The endodermis is distinct and limit the inner side of the cortex, and then a pericycle surrounding a continuous ring of vascular tissue a wide parenchymatous pith which is free from content occupies the central part of the stem.

In the moderately old stem (Fig. 4) the cortex is comparatively narrow, the innermost layer of cortex parenchyma is collapsed and the endodermis becomes indistinguishable. The pericyclic fibres form larger groups. After secondary thickening both phloem and xylem zones increased and numerous secondary lignified medullary rays transverse the secondary vascular elements.

\section{The epidermis (Fig. 4B)}

The epidermis consists of one layer of square to subrectangular cells with thick wall as seen in transverse section, but in surface view (Fig. 3B) the cells are polygonal, axially elongated with more or less straight and beaded anticlinal walls. The cells are covered with thick smooth cuticle, measuring about $12-45 \mu$ in length, $7-20 \mu$ in width and $10-20 \mu$ in height. Numerous slightly sunken stomata of paracytic type are present. The stomata is oval to rounded surrounded by 2 (rarely 3-4 subsidiary cells), and measuring about $15-20 \mu$ in diameter. Few covering trichomes are observed. The hair is unicellular with thick wall, narrow lumen filled with dark brown pigments, showing acute to acuminate apex and covered with warty cuticle. It measures about $130-250 \mu$ in length and 7-13 $\mu$ in width.

\section{The cortex (Fig. 4)}

The cortex is formed of 2-3 rows of thickwalled cellulosic collenchymatous cells being rounded to ovoid in shape, followed by an inner parenchymatous region consisting of 6-9 layers, the innermost rows of which are collapsed. The cells adjacent to the pericycle form a crystal sheath of calcium oxalate which measures 13-18 $\mu$ in length and 5-10 $\mu$ in width.

\section{The pericycle (Fig. 4)}

The pericycle consists of more or less complete ring of 2-5 layers of lignified fibres. The fibre (Fig. 3B) has a lignified thick wall, with narrow sometimes fairly wide lumen and acute to acuminate apex. The lumina widen gradually as it approach the phloem. It measures about $700-800 \mu$ in length and from $10-20 \mu$ in diameter. The parenchymatous cells surrounding the fibres contain prisms of calcium oxalate forming a well developed crystal sheath. 


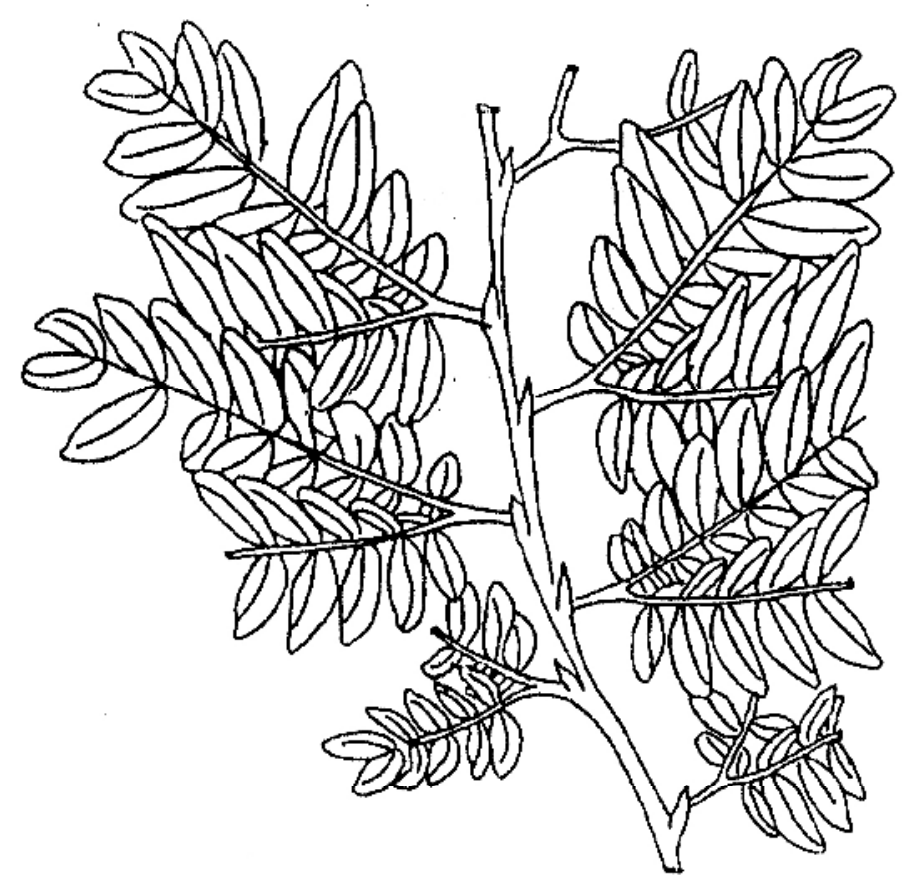

A
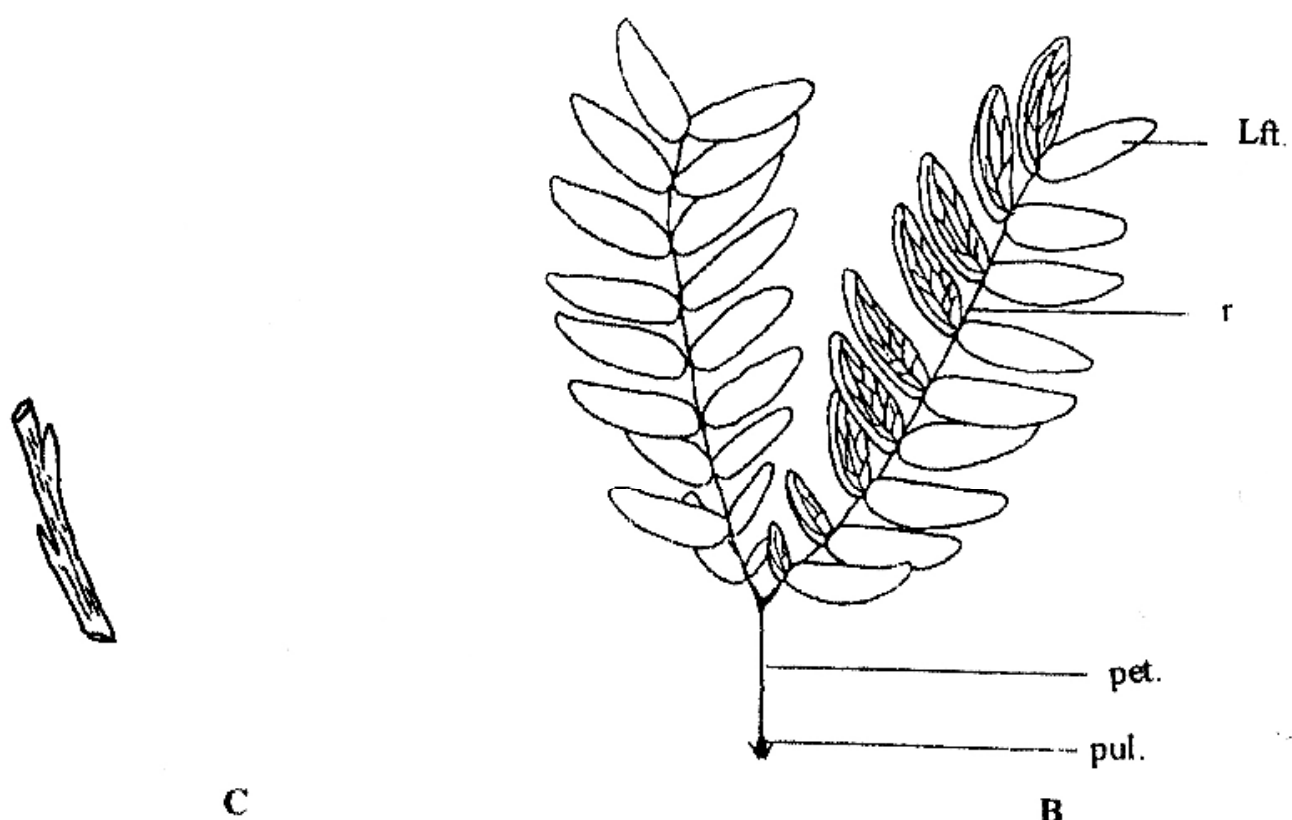

Fig. 2: A- Sketch of young branch

B- Sketch of the leaf

C- Sketch of moderately old stem

Lft., leaflet; pet., petiole; pul., pulvinus; r., rachis. 

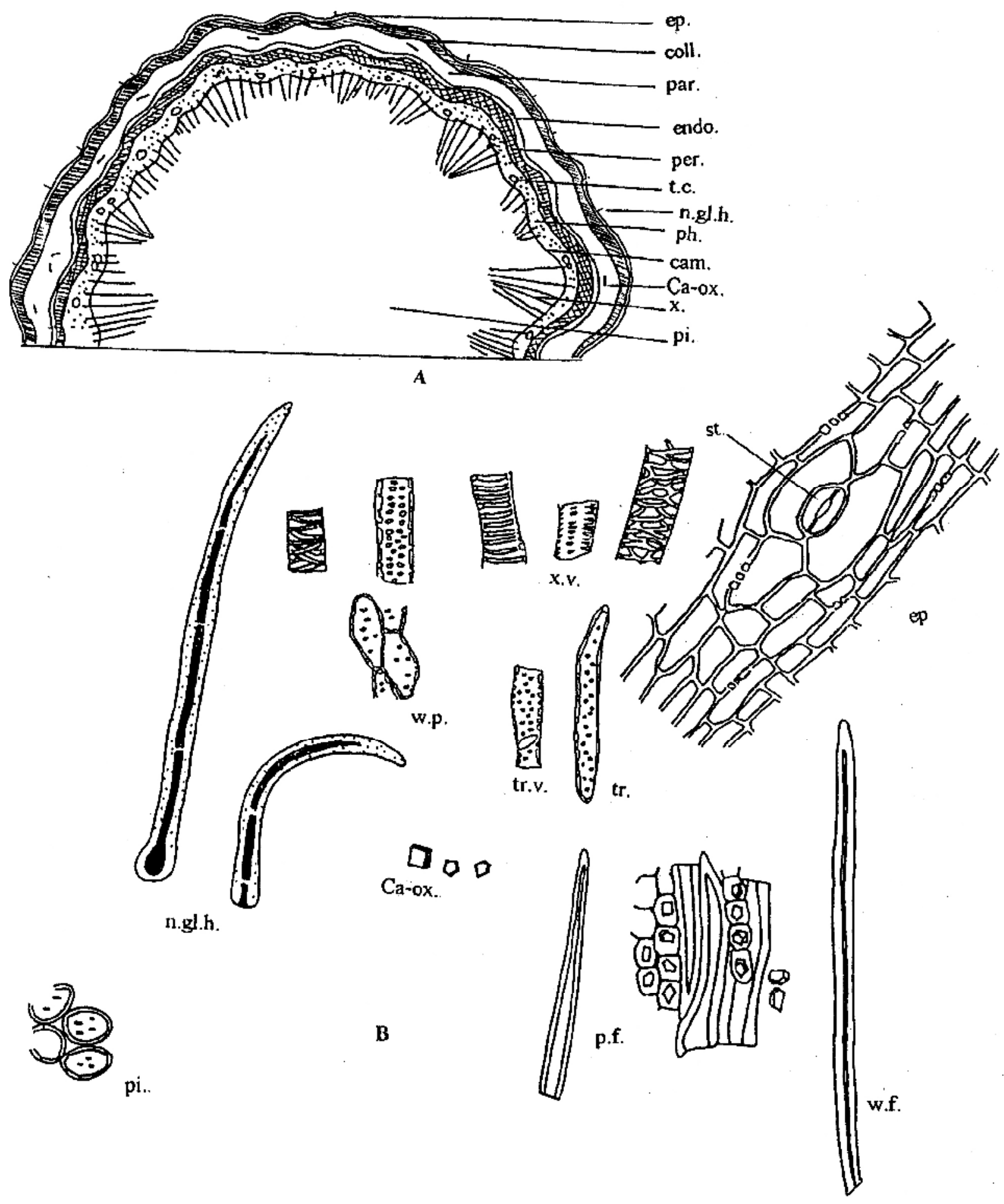

Fig. 3: A- Diagrammatic T.S. of young stem B- Isolated elements of stem

ca-ox., calcium oxalate; cam., cambium; coll., collenchyma; endo., endodermis; ep., epidermis; n.gl.h., non-glandular hair; par., parenchyma; per., pericycle; p.f., pericyclic fibre; ph., phloem; pi., pith; st., stomata; t.c., tanniniferous cell; tr., tracheid; tr.v., tracheidal vessel; w.f., wood fibre; w.p., wood parenchyma; x., xylem; x.v., xylem vessels. 

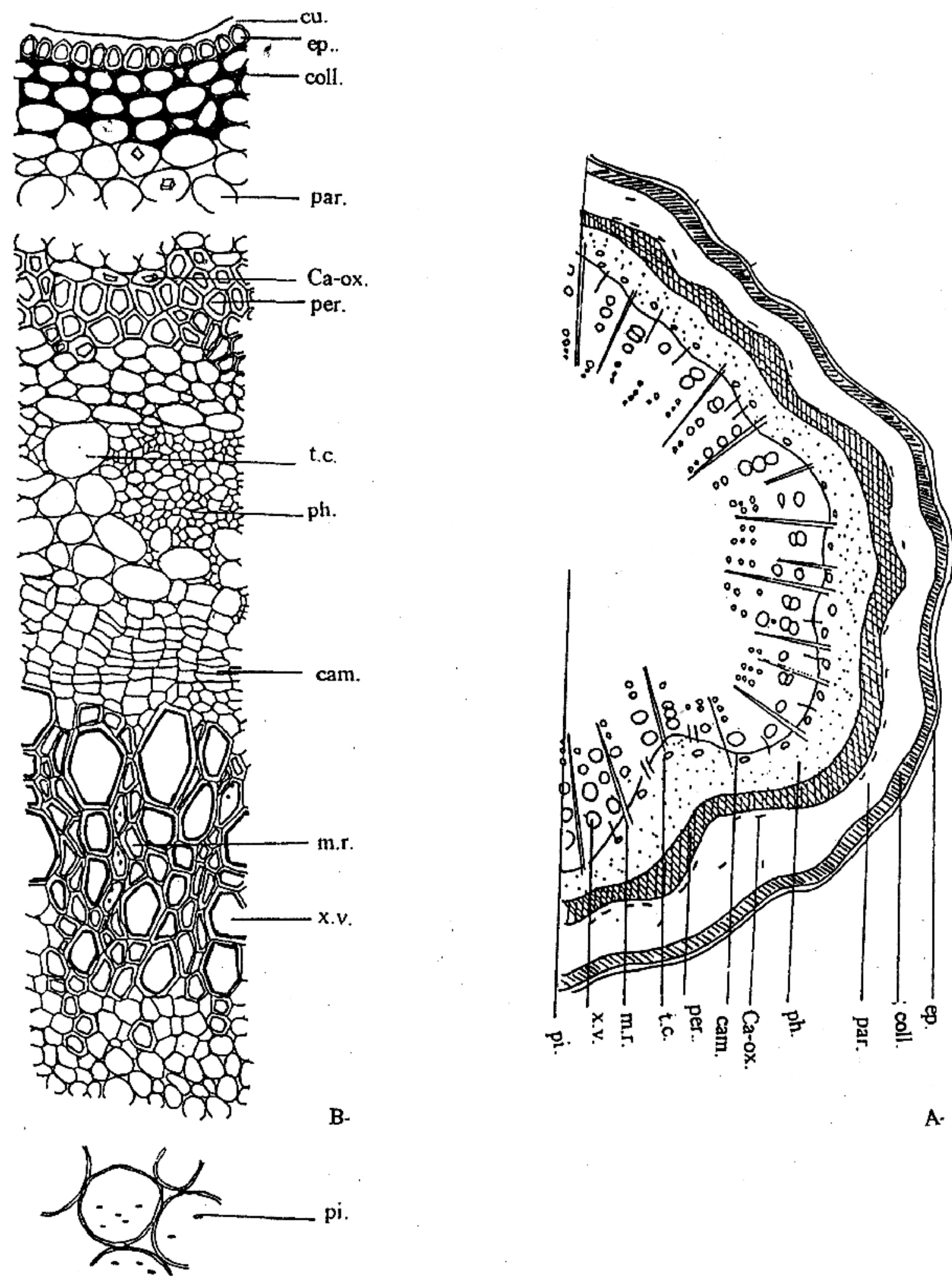

A.

Fig. 4: A- Diagrammatic T.S. of moderate stem

B- Detailed T.S. of the stem

ca-ox., calcium oxalate; cam., cambium; coll., collenchyma; cu., cuticle; ep., epidermis; m.r., medullary ray; par., parenchyma; per., pericycle; ph., phloem; pi., pith; t.c., tanniniferous cell; x.v., xylem vessel. 


\section{The phloem (Fig. 4)}

The phloem is formed of a complete ring of mostly secondary phloem surrounding the xylem. It consists of thin walled, cellulosic soft elements of sieve tube, companion cells and phloem parenchyma, colourless tanniniferous cells $^{23,24}$ are scattered. It gives no characteristic colour with ferric chloride. No fibres are observed.

\section{The cambium: (Fig. 4B)}

The cambium forms a wide band of cambiform cells consisting of 5-7 layers of thin-walled cellulosic cells which are subrectangular, tangentially elongated and radially arranged.

\section{The xylem (Figs. 3B \& 4)}

The xylem is represented by a ring of primary and secondary xylem elements. The secondary xylem is the main constituent and consists of lignified, thick-walled elements, arranged in radial rows.

The vessels are mostly in groups of 3-4 vessels, most of which possess thick walls with simple or bordered pits. Some of the vessels show pitted, scalariform, reticulated and spiral thickening measuring from $10-50 \mu$ in diameter.

\section{The wood fibres (Fig. 3B)}

The wood fibre has a thick lignified wall, moderately narrow lumen and an acute to acuminate apex. It measures about 450-600 $\mu$ in length and 5-10 $\mu$ in diameter. The vessels are accompanied by lignified tracheidal vessels and tracheids which measure about 11-20 $\mu$ in diamter.

\section{The wood parenchyma (Fig. 3B)}

They are few, consist of axially elongated subrectangular cells with lignified pitted walls.

\section{The primary xylem (Figs. 3B \& 4) \\ It is formed of lignified mainly spiral and pitted vessels with thin walled wood parenchyma.}

\section{The medullary rays (Fig. 4)}

The secondary medullary rays are usually uni- to biserriate formed of elongated subrectangular cells having lignified walls some of them showing simple pits in the xylem region, but in the phloem region the medullary rays cells are cellulosic with thin walls.

\section{The pith (Fig. 4)}

The pith is wide, formed of round parenchymatous cells mostly with slightly lignified and pitted walls, but no calcium oxalate crystals are observed.

\section{The powdered stem (Fig. 3B)}

It is yellowish-green in colour with faint odour and salty astringent taste, it is characterised microscopically by the following:

1- Fragments of epidermal cells with paracytic stomata, the cells are axially elongated polygonal with straight slightly beaded anticlinal walls and covered with smooth thick cuticle. Some fragments carry non-glandular, unicellular hairs which are slightly curved having thick walls and narrow lumina, with acute to acuminate apices and covered with warty cuticle.

2- Fragments of lignified pericyclic fibres surrounded by parenchyma cells contain prismatic crystals of calcium oxalate, each one has a thick lignified wall with narrow sometimes fairly wide lumen and acute to acuminate apex.

3- Fragments of lignified spiral, scalariform, reticulated and pitted xylem vessels.

4- Fragments of tracheidal vessels and tracheids with pitted lignified walls.

5- Fragments of rectangular to subrectangular wood parenchyma with thin lignified pitted walls.

6- Fragments of parenchyma of pith with lignified pitted walls.

7- Numerous scattered prisms of calcium oxalate.

8- Starch is absent.

\section{2- The Leaf}

\section{Macromorphology of the leaf (Fig. 2)}

The leaves are alternate, stipulate, petiolate and bipinnately compound with one pair of pinnae, each with 7-10 pairs of elliptic to oblong-lanceolate sessile leaflets. Each leaflet has obtuse to mucronate apex, obliquely rounded to subcordate base, entire margin and slightly hairy surface. It is green in colour and measure about $0.5-3.7 \mathrm{~cm}$ long and $0.3-1.3 \mathrm{~cm}$ width at the middle portion. The vennation is 
pinnate-reticulate, the veins are prominent on the lower surface, and leave the midrib at an acute angle.

The petiole is cylindrical to subcylindrical, green in colour, measure about $3-4 \mathrm{~cm}$ in length, from about $0.3-0.5 \mathrm{~mm}$ in diameter and usually has a swollen base called pulvinus.

The rachis is subtriangular to cordate in outline and shows two prominant ridges on the upper surface. It has a green colour and measures about $10-15 \mathrm{~cm}$ in length and about $0.5-0.7 \mathrm{~mm}$ in diameter, the surface is hairy.

The dried leaves are brittle, with faint odour and slightly astringent taste.

\section{Micromorphology of the leaflet: \\ The lamina (Fig. 5A, 5B \& 6A)}

A transverse section through the lamina of the leaflet is biconvex in outline. It shows isobilateral structure with continuous upper and lower discontinuous palisade layers, the lower palisade is interrupted in the midrib region by a mass of subepidermal collenchymatous cells.

The midrib region of old leaflet (Figs. 5A \& 6A) shows a large central arc of vascular tissue with xylem above and phloem below. Both are surrounded by a continuous band of pericyclic fibres, which is interrupted by a small inverted vascular bundle at its upper part.

But in the transverse section of young leaflets (Fig. 5B) the pericycle formed of upper and lower arcs, without being interrupted by any accessory vascular bundle. Both lower and upper epidermises containing paracytic stomata and carrying few unicellular non-glandular and rare glandular trichomes.

The cells of mesophyll contain prisms of calcium oxalate specially those adjacent to pericyclic fibre forming crystal sheath.

\section{The upper epidermis (Fig. 6)}

The upper epidermis consists of one row of square to subrectangular cells as seen in transverse section. In surface view, the cells are polygonal with sinuous anticlinal walls. The cells are covered with thick smooth cuticle, they measure about $16-40 \mu$ in length, $10-25 \mu$ in width and $12-20 \mu$ in height. The cells over the midrib and big veins are slightly elongated with somewhat straight anticlinal walls and measure about 8-20 $\mu$ in length, 6-16 $\mu$ in width and 20-25 $\mu$ in height.

Stomata of paracytic type (somewhat sunken) are present, surrounded by two rarely three to four subsidiary cells, the stomata measures about 8-20 $\mu$ in diameter and 14-30 $\mu$ in length.

Few covering and glandular trichomes are present. The non-glandular hairs are unicellular, slightly curved with acute to acuminate apices, covered with warty cuticle, show wide or narrow lumina, they measure about $80-120 \mu$ in length and $7-13 \mu$ in width.

The rare glandular hairs may be either with short unicellular stalks and multicellular spherical heads of 5-8 cells arranged irregularly or uniserriate stalks of 3-4 cells and ellipsoidal heads.

\section{The lower epidermis (Fig. 6)}

The lower epidermis is formed of one row of cells which are similar to those of upper epidermis except that they possess more sinuous anticlinal wall and numerous paracytic stomata. It measures about $6-30 \mu$ in length, 4$20 \mu$ in width and 10-15 $\mu$ in height. Stomata and hairs being exactly identical to those of upper epidermis.

\section{The mesophyll (Figs. 5A, 5B, 6A \& 6B)}

The mesophyll tissue is isobilateral with upper and lower palisade layers abutting on both upper and lower epidermises enclosing in between a narrow spongy tissue. The upper palisade is continuous in the midrib region and is formed of two rows in the lamina region and then reduced to one row in the midrib region, they are columnar cells closely packed with indistinct intercellular spaces and containing chloroplasts. The outer palisade cells are longer than the inner ones, and the cells of the same layer varies in their length. They measure about 10-35 $\mu$ in length and 4-16 $\mu$ in width.

The lower palisade cells are shorter than the cells of the upper one and are not continuous in the midrib region being interrupted by a mass of collenchymatous cells. Palisade is formed of a regular single layer with narrow intercellular spaces. The cells of the lower palisade measure about 6-25 $\mu$ in length and 4-16 $\mu$ in width. 


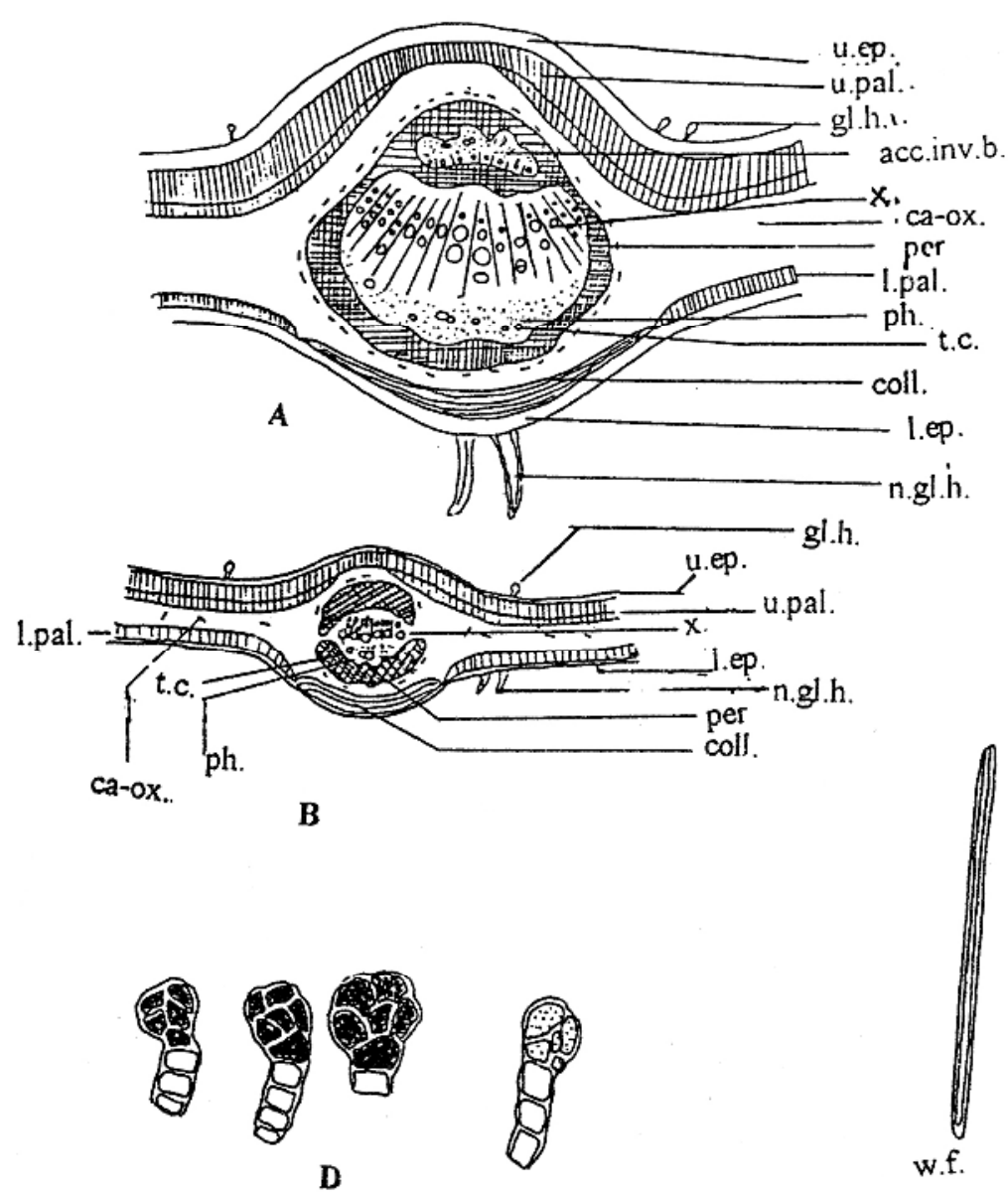

Fig. 5: A- Diagrammatic T.S. of old leaflets at midrib region $\quad x 89.6$ C- Isolated elements of the leaf with rachis and petiole $\mathrm{x} 400$
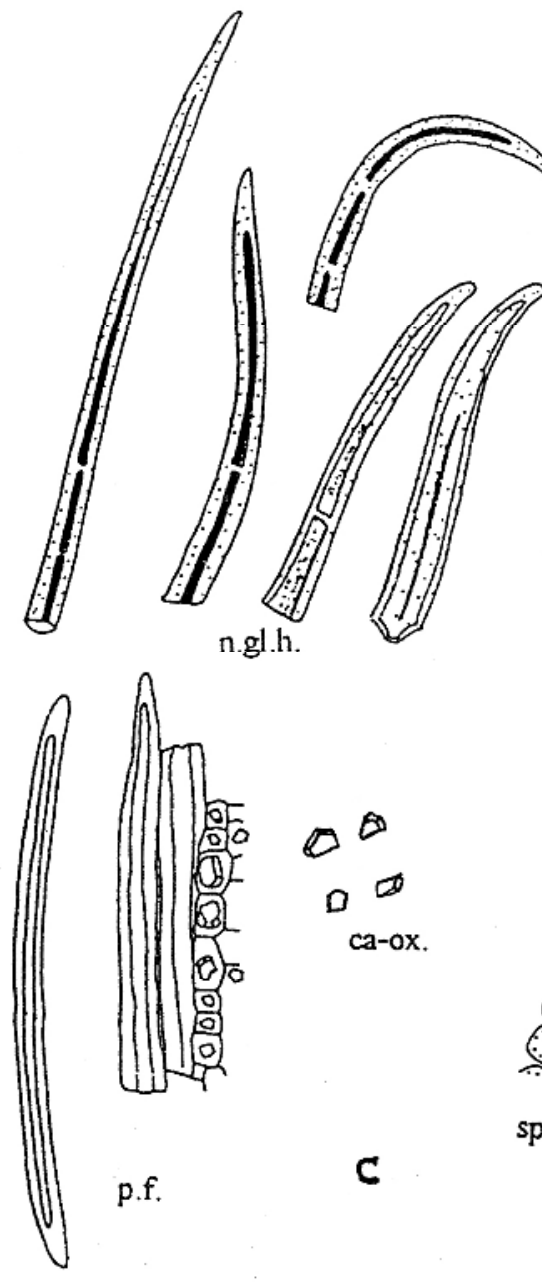

0

ca-ox.

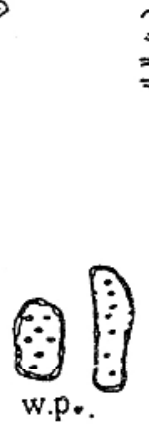

st.
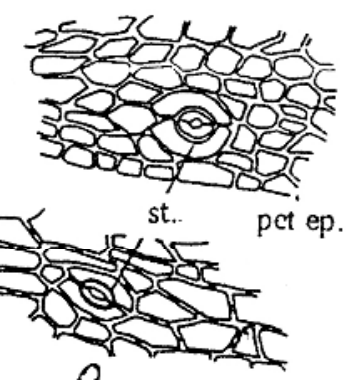

$\theta$ r.ep.

:

tr.v.

tr.

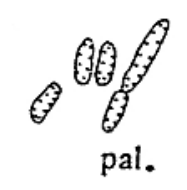

C

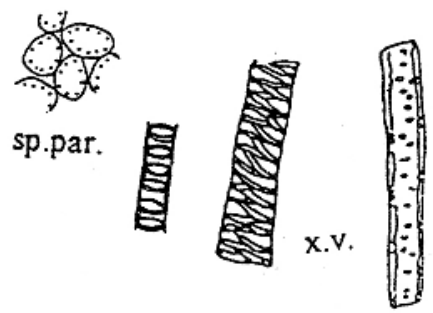

B- Diagrammatic T.S. of young leaflets at midrib region $\mathrm{x} 120$ D- Glandular hairs

$\mathrm{x} 1000$

acc.inv.b., accessory inverted vascular bundle; ca-ox., calcium oxalate; coll., collenchyma; gl.h., glandular hair; l.ep., lower epiderms; l.pal., lower palisad; n.gl.h., non-glandular hair; p.f., pericyclic fibre; pal., palisade; per., pericycle; pet.ep., petiole epidermis; ph., phloem; r.ep., rachis epidermis; sp.par., spongy parenchyma; st., stomata; t.c., tanniniferous cell; tr., tracheid; tr.v., tracheidal vessel; u.ep., upper epidermis; u.pal., upper palisade; w.f., wood fibre; w.p., wood parenchyma; x., xylem; x.v., xylem vessel. 

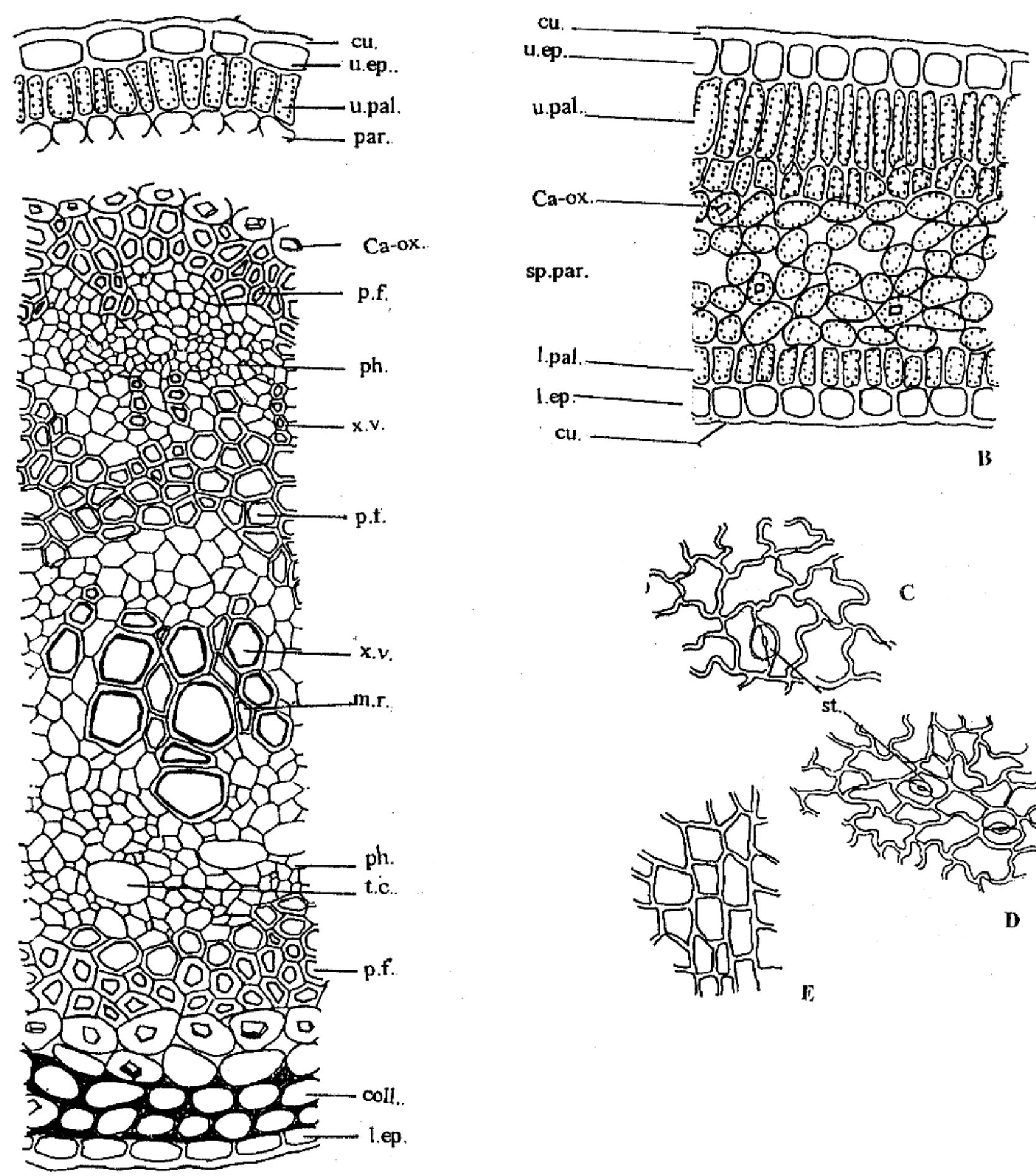

A

Fig. 6: A- Detailed T.S. of old leaflet at midrib region $\quad$ x 400 B- Detailed T.S. in the lamina

C- Surface preparation of the leaflet (upper epidermis)

D- Surface preparation of the leaflet (lower epidermis)

x 500

E- Surface preparation of the leaflet (midrib region)

x 500

ca-ox., calcium oxalate; coll., collenchyma; cu., cuticle; 1.ep., lower epidermis; 1.pal., lower palisade; m.r., medullary ray; p.f., pericyclic fibre; par., parenchyma; ph., phloem; sp.par., spongy parenchyma; st., stomata; t.c., tanniniferous cell; u.ep., upper epidermis; u.pal., upper palisade; x.v., xylem vessel. 
The rest of mesophyll (Fig. 6B) is formed of a narrow zone of rounded cells, with wide intercellular spaces and through which the vascular strands of lateral veins run.

Many cells contain prisms of calcium oxalate, specially those surrounding the pericyclic fibres, forming a crystal sheath. Each prism measures about 14-50 $\mu$ in length and 6$20 \mu$ in width.

\section{The cortical tissue (Fig. 6A)}

The cortical tissue of the midrib and big veins consists of few layers of cellulosic, rounded to tangentially elongated parenchyma cells with narrow intercellular spaces above and below the bundle, in addition to a small mass of 2-3 layers of subepidermal collenchyma abutting on the lower epidermis. Some of parenchyma cells contain prisms of calcium oxalate but those adjacent to the fibres of the pericycle forming crystal sheathes.

\section{The pericycle (Figs. $5 \& 6 \mathrm{~A}$ )}

In the transverse section of the midrib region of young leaflets (Fig. 5B) the pericyle is formed of upper and lower arcs, without being interrupted by any accessory vascular strand.

In the midrib region of old leaflets the vascular strand is surrounded by a continuous band of pericyclic fibres which is interrupted by a small inverted accessory vascular bundle at its upper part. The upper part is formed of 58 layers of lignified fibres, while the lower one is formed of 3-5 layers. Both upper and lower pericycle are sinuated in outline.

The fibres are elongated having thick lignified walls, moderately wide lumina, and blunt apices. They measure about $180-300 \mu$ in length, and 10-14 $\mu$ in diameter. The pericyclic fibres are surrounded by a crystal sheath.

\section{The vascular system (Figs. 5A, 5B \& 6A)}

The vascular system is represented by a large collateral vascular bundle situated in the midrib region formed of xylem above and phloem below, and surrounded by a more or less continuous band of pericyclic fibre. According to the leaflet age, an accessory inverted vascular bundle may appear embedded in the upper part of pericyclic fibre.

\section{The xylem zone (Figs. 5C \& 6A)}

Consists of vessels, tracheids, fibres, wood parenchyma, and is transversed by narrow medullary rays. The xylem vessels are lignified with pitted, spiral and rarely annular thickening, measuring about 4-15 $\mu$ in diameter.

The wood parenchyma consists of subrectangular, polygonal and non-lignified cells.

The medullary rays are usually 1-2 cells width. The cells are subrectangular in shape with non-lignified or slightly lignified walls. Wood fibres are similar to those of the pericycle and occur in small groups.

The phloem is composed of thin-walled, cellulosic elements, some of phloem parenchyma contain prisms of calcium oxalate. Few tanniniferous cells ${ }^{23,34}$ are present. No fibres are observed.

Micromorphology of the leaf rachis (Fig. 7A)

A transverse section in the rachis is more or less subcordate in outline, with a groove on the upper side limited by two prominent ridges. The rachis shows an epidermis, carries numerous hairs and enclosing a narrow cortex. The palisade present beneath the upper area consists of one row of small subcylindrical cells continuous till the heighest point in the prominent ridge.

The vascular system is represented by a large central vascular cylinder and two small lateral inverted vascular bundles located beneath the upper prominent ridges. The vascular cylinder is surrounded by a more or less complete ring of lignified pericyclic fibres and is embedded in parenchymatous cortex.

The cylinder consists of a large concentric vasocentric structure with inner xylem and outer phloem surrounding a wide central parenchymatous pith. The endodermis is usually indistinct.

The small accessory bundles in the two prominent ridges are collateral showing their phloem directed toward the upper side and xylem below it. The bundles are crowned with arcs of sinuated pericycle.

Prisms of calcium oxalate are scattered in the parenchyma particularly around the fibres forming crystal sheathes. 
The epidermis (Figs. 7B \& 8)

The epidermis consists of one layer of square to subrectangular cells with thick walls, but in surface view the cells are polygonal, axially elongated, with straight beaded anticlinal walls, having smooth cuticle, measuring about 6-24 $\mu$ in length, 4-10 $\mu$ in width and $4-8 \mu$ in height. Numerous stomata mainly of paracytic type are present.

The stomata is oval to rounded, surrounded usually by 2-3 (very rare 4) subsidiary cells measuring about $14-30 \mu$ in length and 10-20 $\mu$ in diameter.

The epidermis is hairy, the hairs are of glandular and non-glandular types similar to those in leaflets.

\section{The mesophyll (Figs. 7A \& 8)}

The mesophyll is heterogenous and nonsymmetric, the palisade-like layer is continuous beneath the upper epidermis and it's formed mainly of one layer. The palisade-like cells are short, closely packed, being columnar and perpendicular to the epidermis. The spongy tissue is much reduced forming a very narrow zone of collapsed chlorenchyma below the palisade, it can't be easily differentiated for the cortex. Few prisms of calcium oxalate crystals are observed.

\section{The cortical tissue (Figs. 7A \& 8)}

The cortical tissue surrounds the vascular system separating it from the mesophyll. It's formed of about 1-2 layers of parenchyma cells around the accessory inverted vascular bundles. The number of parenchyma layers increases toward the central vascular cylinder to reach 35 layers of rounded parenchymatous cells showing intercellular spaces, the inner layer of parenchyma cells being collapsed contain prisms of calcium oxalate to form crystal sheathes around pericyclic fibres.

\section{The vascular system (Figs. 5C, 7A \& 8)}

The vascular system, in the upper part of rachis, consists of a large concentric structure with inner xylem and outer phloem, in addition to two small accessory inverted vascular bundles in the two prominent ridges.

The main vascular bundle somewhat similar to that of the stem and it is also surrounded by a complete ring of 5-8 rows of lignified pericyclic fibres. The pericycle is somewhat sinuated in outline.

The pericyclic fibre is straight, has thick lignified wall, narrow sometimes fairly wide lumen, and acute to acuminate apex, it is measuring about 200-650 $\mu$ in length and 8-14 $\mu$ in diameter.

The parenchymatous cells around the fibre show a well-developed crystal sheath of prisms of calcium oxalate. The prisms are somewhat small and measure about 8-20 $\mu$ in length and 4-12 $\mu$ in width.

The phloem consists of soft elements of sieve tubes, companion cells and phloem parenchyma. Many tanniniferous cells ${ }^{23,24}$ are observed. They are colourless cellulosic giant cells of undetermined content.

The phloem zone is separated from xylem by a cambium which forms a comparatively narrow band of cambiform cells consisting of 3-4 layers of thin walled cellulosic cells. The xylem is radiated, formed of lignified vessels, fibres, wood parenchyma, tracheids and traversed by medullary rays of 1-2 cells wide.

The xylem vessels are lignified with pitted, scalariform and spiral thickening measuring about 4-45 $\mu$ in diameter (Fig. 5C).

The wood fibre possesses a thick lignified wall, acuminate apex and narrow lumen measuring about 400-700 $\mu$ in length and 6-14 $\mu$ in diameter. The wood parenchyma are subrectangular in shape with lignified pitted walls.

The tracheids are lignified showing pitted and reticulated thickening and measure about 40-65 $\mu$ in length and 6-25 $\mu$ in diameter.

The pith is wide and central. It is formed of slightly lignified rounded parenchymatous cells which are free from content.

Micromorphology of the leaf petiole(Fig. 9A)

A transverse section in the leaf petiole is more or less circular or subcircular in outline. There is a marked depression in the upper side with two prominent ridges. It has an outer epidermis surrounding the cortical tissue. The endodermis is indistinct.

The vascular system is represented by four to six vascular bundles, in addition to two accessory collateral bundles are present on the dorsal side. Each one consists of phloem, xylem and pericyclic fibres. Prisms of calcium 

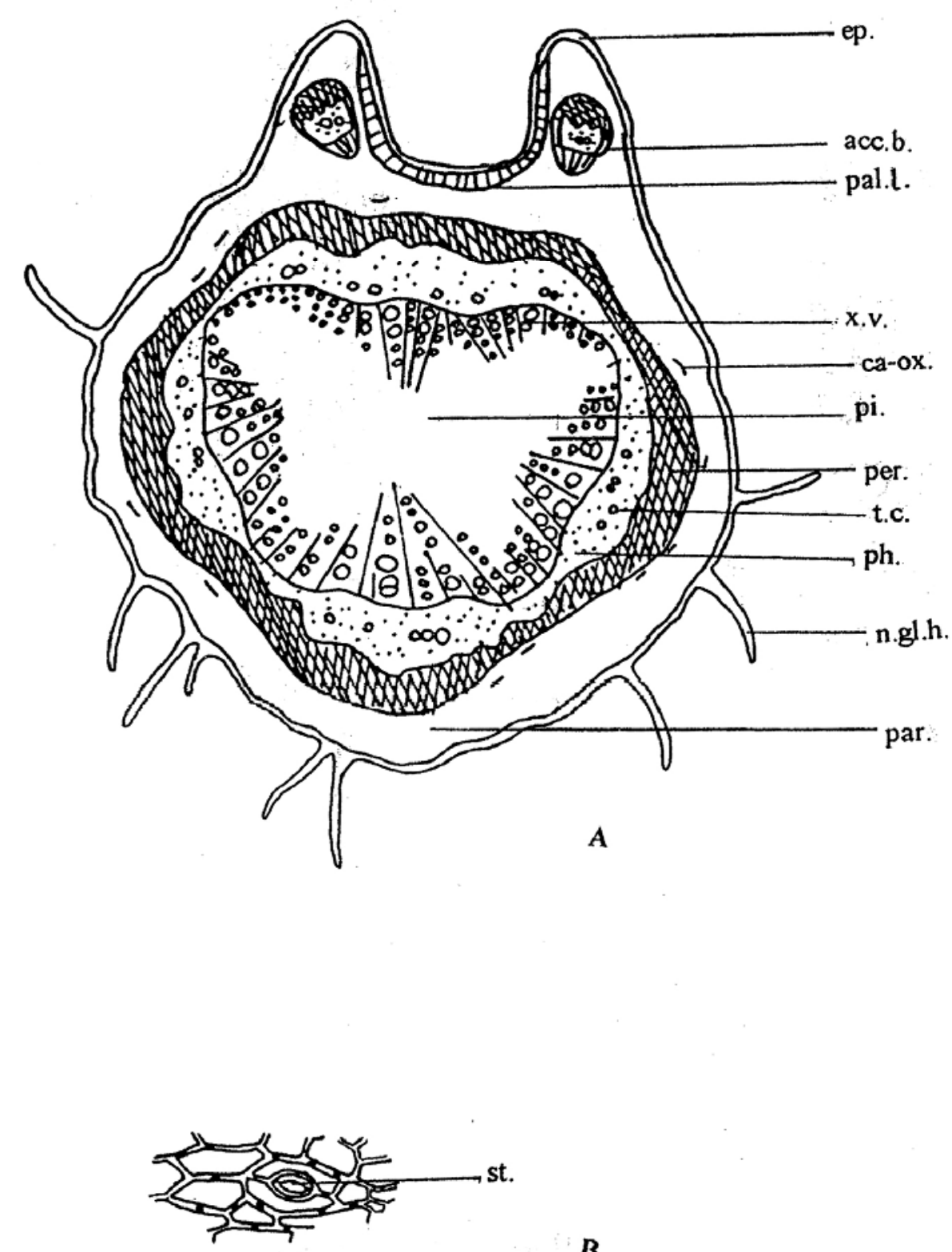

B

Fig. 7: A- Diagrammatic T.S. of leaf rachis

$\mathrm{x} 125$

B- Surface preparation of leaf rachis

x 500

acc.b., accessory vascular bundle; ca-ox., calcium oxalate; ep., epidermis; n.gl.h., non-glandular hair; pal.l., palisade like cells; par., parenchyma; per., percycle; ph., phloem; pi., pith; st., stomata; t.c., tanniniferous cell; x.v., xylem vessel. 

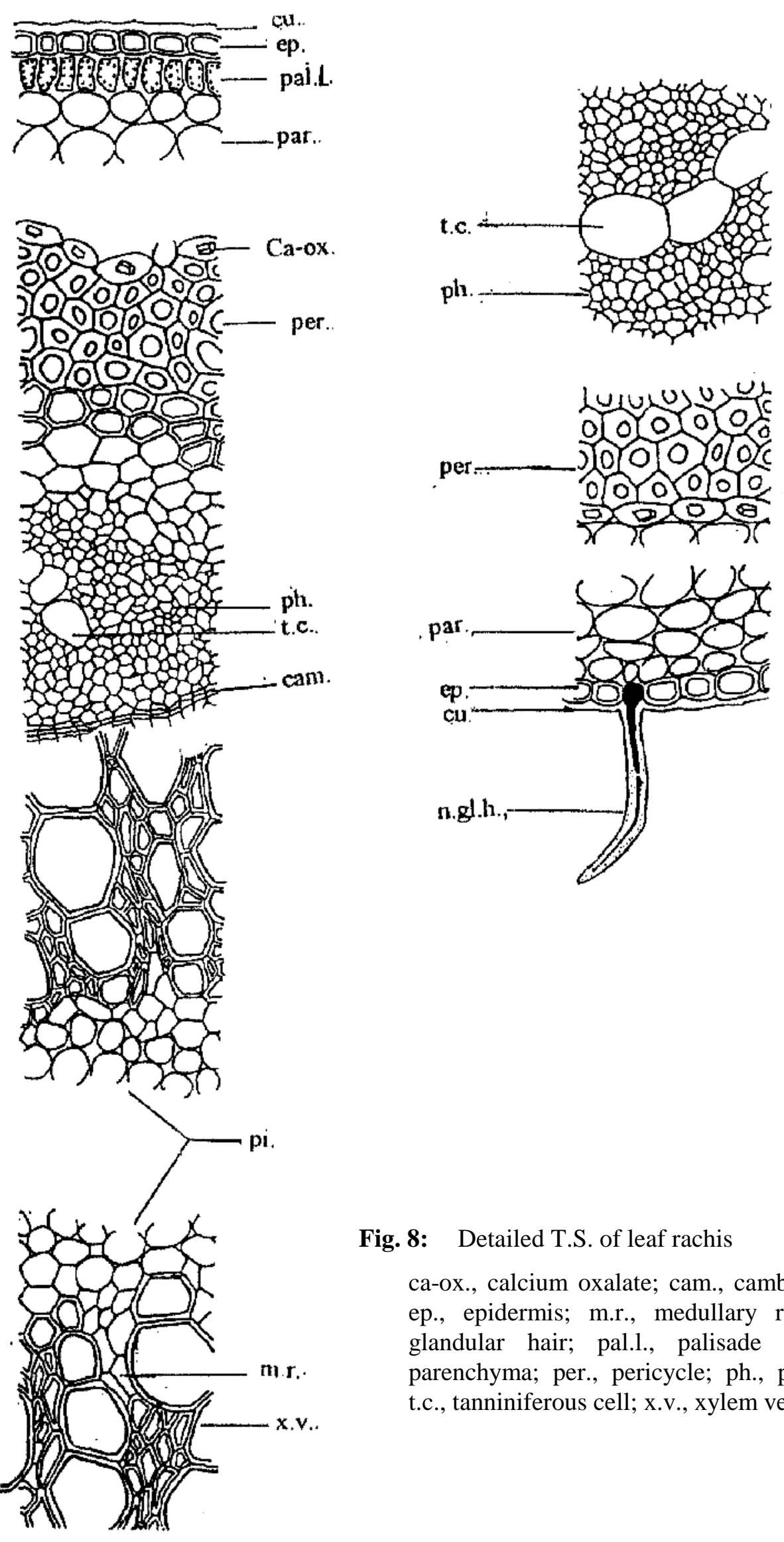

Fig. 8: Detailed T.S. of leaf rachis

x 320

ca-ox., calcium oxalate; cam., cambium; cu., cuticle; ep., epidermis; m.r., medullary ray; n.gl.h., nonglandular hair; pal.1., palisade like cells; par., parenchyma; per., pericycle; ph., phloem; pi., pith; t.c., tanniniferous cell; x.v., xylem vessel. 
oxalate are scattered in the parenchyma cells particularly around the fibres forming crystal sheathes.

\section{The epidermis (Figs. 9B \& 10)}

The epidermis consists of one layer of subrectangular cells as seen in transverse section, but in surface view the cells are polygonal axially elongated, with more or less straight anticlinal walls and covered with smooth cuticle. It measures about $10-30 \mu$ in length, 6-14 $\mu$ in width and 5-12 $\mu$ in height.

Numerous stomata mainly of paracytic type and somewhat sunken are present.

Both glandular and non-glandular hairs are observed and similar to those of the leaflets.

The cortical tissue (Figs. 9A \& 10)

The cortical tissue formed of an outer collenchymatous zone and an inner parenchymatous one. The collenchymatous zone is formed of 2-3 rows of rounded to oval cells. The parenchymatous zone above the vascular bundles is formed of 5-7 rows of oval cells with intercellular spaces. The parenchymatous cells around the pericyclic fibres contain prisms of calcium oxalate forming a crystal sheath.

\section{The vascular system (Figs. 5C, 9A \& 10)}

The vascular system consists of two groups of vascular strands, the lower vascular strand which consists of 3-4 united collateral vascular bundles and the upper vascular strand which consists of 2-3 united collateral vascular bundles and opposite to the lower one. Both showing an outer phloem and an inner xylem.

In addition to the above, there are 2-4 accessory collateral vascular bundles present under the two prominent ridges (one or two vascular bundles per each), all bundles are crowned with arcs of sinuated pericycle composed of 3-5 rows of pericyclic fibres.

The pericyclic fibre is usually straight, sometimes sinuated in outline. It possesses a thick lignified wall, a narrow; sometimes fairly wide lumen, an acute to acuminate apex and measuring about $350-750 \mu$ in length and 8-14 $\mu$ in diameter.

The fibre is surrounded by parenchymatous cells each contain prisms of calcium oxalate forming a crystal sheath.
The phloem consists of soft elements of sieve tubes, companion cells, phloem parenchyma and tanniniferous cells.

The radiating xylem is formed of lignified vessels, fibres, wood parenchyma and tracheids. It is traversed by medullary rays.

The xylem vessels (Fig. 5C) are lignified with pitted, spiral and annular thickening measuring about 4-45 $\mu$ in diameter. The wood fibre is elongated with tapering end, has a thick lignified wall, a narrow lumen and measuring about 400-700 $\mu$ in length and 6-14 $\mu$ in diameter.

The wood parenchyma are polygonal to subrectangular in shape with lignified pitted walls. The medullary rays in the xylem region are lignified uni- or biserriate.

\section{The powdered leaflets with rachis and petiole}

The powdered leaf is dark green in colour, possessing a faint odour and a slight astringent taste. It is characterized microscopically by the following fragments (Fig. 5C):

1- Fragments of epidermis of lamina consisting of polygonal cells with sinuous anticlinal walls and covered with smooth cuticle showing paracytic stomata, glandular and non-glandular trichomes.

2- Fragments of non-glandular trichomes which are unicellular, slightly curved, with acute to acuminate apices, covered with warty cuticle and showing wide or narrow lumina.

3- Fragments of glandular hairs each one has short unicellular or 3-4 celled stalk and multicellular (5-8 cells) globular head.

4- Fragments of epidermis of rachis and petiole showing polygonal axially elongated cells with straight anticlinal walls, covered with smooth cuticle, containing paracytic stomata and carrying covering trichomes similar to epidermis of lamina in all aspects.

5- Fragments of mesophyll of lamina and rachis showing columnar palisade cells and spongy chlorenchyma containing prisms of calcium oxalate.

6- Fragments of vascular tissues showing spiral, scalariform, pitted and reticulated lignified vessels as well as tracheids and tracheidal vessels with lignified pitted and reticulated walls. Abundant pericyclic and wood fibres with lignified thick walls and 

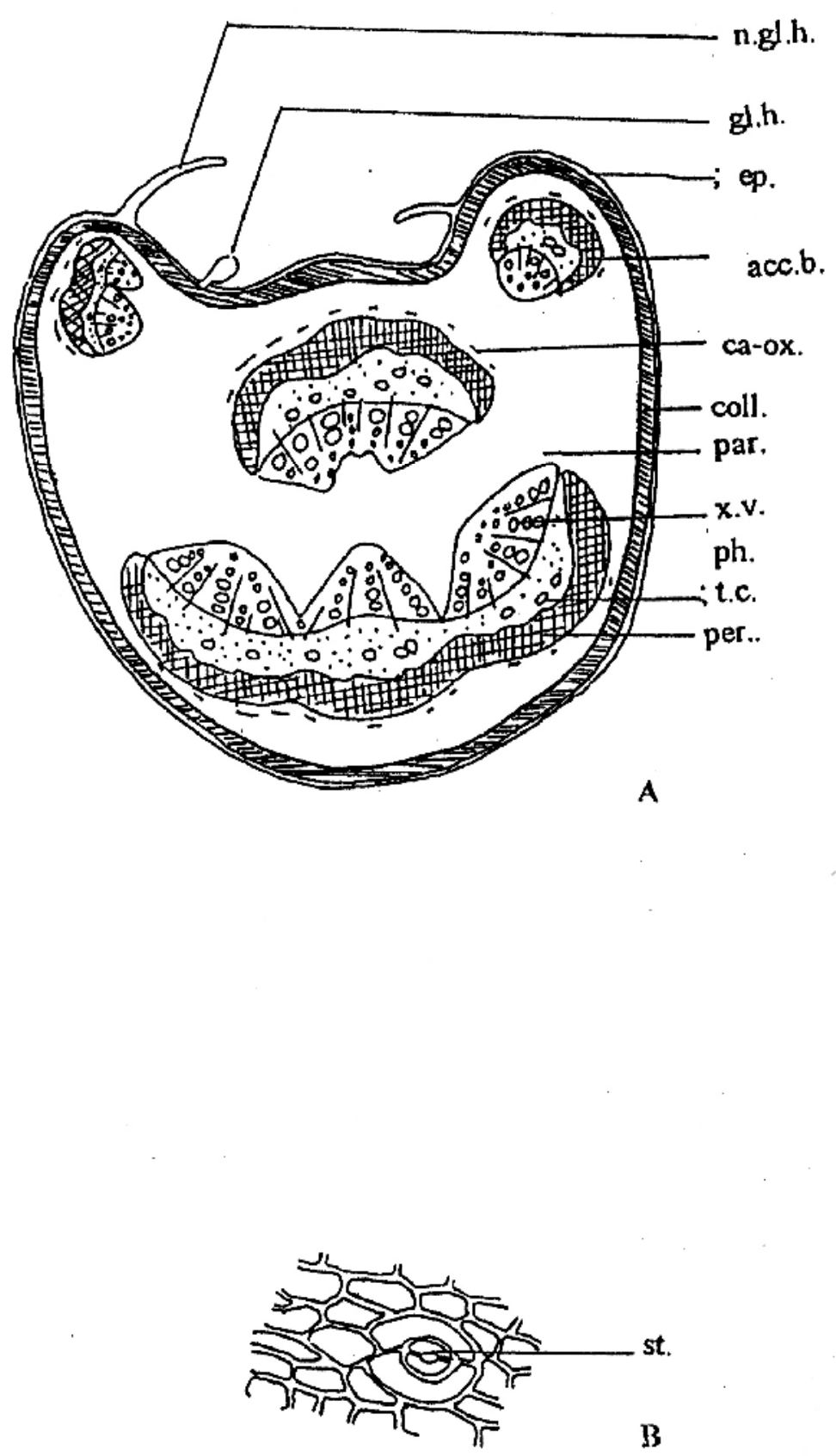

Fig. 9: A- Diagrammatic T.S. of leaf petiole

acc.b., accessory vascular bundle; ca-ox., calcium oxalate; coll., collenchyma; ep., epidermis; gl.h., glandular hair; n.gl.h., non-glandular hair; par., parenchyma; per., pericycle; ph., phloem; st., stomata; t.c., tanniniferous cell; x.v., xylem vessel. 

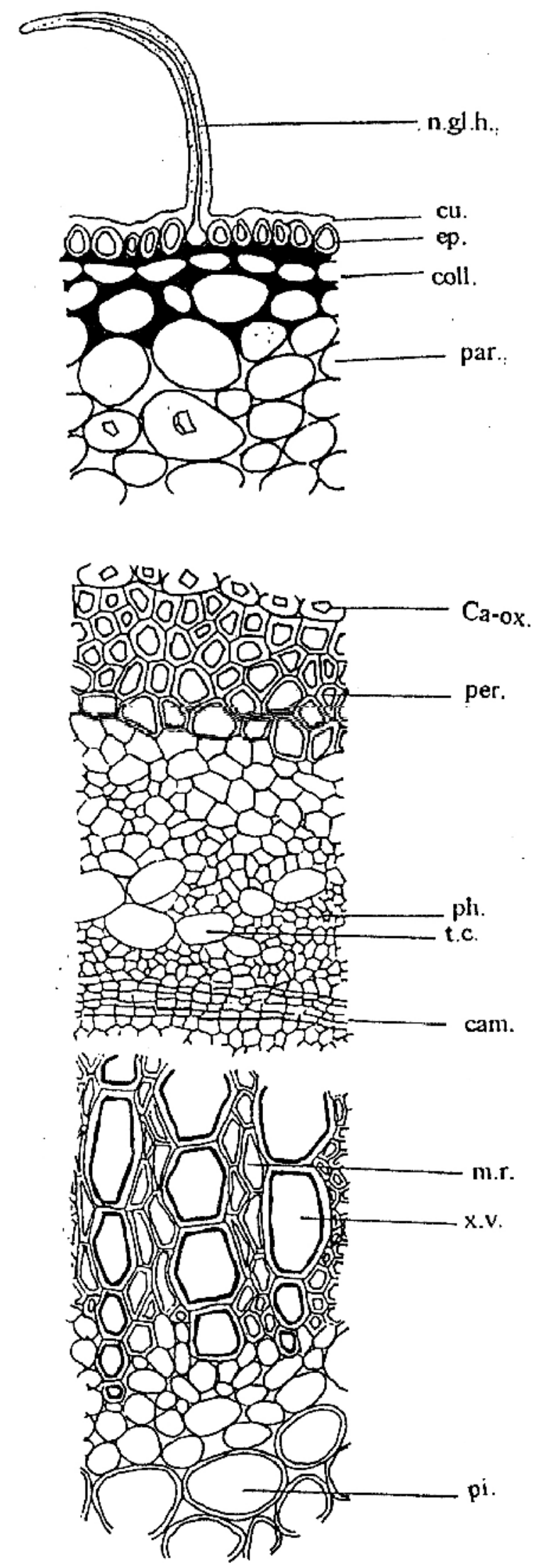

Fig. 10: Detailed T.S. of leaf petiole

x 360 ca-ox., calcium oxalate; cam., cambium; coll., collenchyma; cu., cuticle; ep., epidermis; m.r., medullary ray; n.gl.h., nong-glandular hair; par., parenchyma; per., pericycle; ph., phloem; pi., pith; t.c., tanniniferous cell; x.v., xylem vessel. 
surrounded by crystal sheath of prismatic crystals of calcium oxalate.

7- Fragments of wood-parenchyma with lignified pitted walls and wide lumen.

8- Abundant prismatic crystals of calcium oxalate.

9- Starch is absent.

\section{Leaf measurements}

\begin{tabular}{||c|c|c||}
\hline $\begin{array}{c}\text { Leaf } \\
\text { measurement }\end{array}$ & \\
\hline Palisade ratio & & $9.8-\underline{14}-20$ \\
\hline Stomatal number & upper surface & $22.8-\underline{24}-25.1$ \\
& lower surface & $24.2-\underline{32} .2-34$ \\
\hline Stomatal index & upper surface & $13.1-\underline{13.5}-13.8$ \\
& lower surface & $13.3-\underline{14.2}-15.2$ \\
\hline Vein ilets number & & $16-32$ \\
\hline
\end{tabular}

\section{REFERENCES}

1- "Index Kewensis" Otto Koeltz Science Publishers, Koenigstein, West Germany, p. 385 (1978).

2- L. H. Bailey and E. Zoe Bailey, "Hortus Third, A Concise Dictionary of Plants Cultivated in the United States and Canada", Macmillan Publishing Co., INC (New York), and Collier Macmillan Publishers (London), p. 201 (1976).

3- L. Benson, "Plant Classification", Oxford and IBH Publishing Co., New Delhi, Calcutta and Bombay, pp. 244-5 (1957).

4- J. F. Williamson, "Sunset Western Garden Book", Lan Publisher Co., Menlo Park Calf, p. 256 (1981).

5- L. H. Bailey, "The Standard Cyclopedia of Horticulture", by the Macmillan Company, New York, p. 628 (1968).

6- G. H. M. Lawerence, "Taxonomy of Vascular Plants", The Macmillan Company, New York, pp. 545-7 (1951).

7- J. L. Diaz, "Index y Sinonoma de Las Plantas Medicinales de Mexico", Instituto Mexicanopara el Estudio de las Plantas Medicinales, Mexico City, p. 16 (1976). Through Chem. Pharm. Bull., 46, 723 (1998).

8- E. S. Ayensu, "Medicinal Plants of West Africa", Reference Publications, INC, pp. 183-6 (1978).
9- M. I. Maurice, "Handbook of African Medicinal Plants", CRC Press, Boca Roton Ann Arbor London, Tokyo, pp. 47, 352 (1993).

10- C. N. Aguwa and A. M. Lawal, J. Ethnopharmacol., 22, 63 (1988).

11- P. A. Akah and J. I. Nwaiwa, J. Ethnopharmacol., 22, 205 (1988).

12- D. R. Encarnacion, R. F. Murillo and M. L. Pantoja, J. Ethnopharmacol., 20, 209 (1987).

13- M. A. Kahn and Z. Ahmad, Fitoterapia, 64, 516 (1993).

14- D. R. Encarnacion and A. N. Ochoa, J. Nat. Prod., 57, 1307 (1994).

15- S. A. Brenner and J. T. Romeo, Appl. Environ. Microbiol., 51, 690 (1986).

16- S. J. Simmonda Monique, T. Romeo John and M. Blaney Wally, Biochem. Syst. Ecol., 16, 623-6 (1988). Through, C.A., 110, 168044f (1989).

17- J. T. Romeo and S. J. Simmonds Monique, ACS Symp. Ser., 387, 59 (1988). Through C.A., 112, 193739k (1990).

18- C.O. Adewunmi and E. K. Adesogan, Fitoterapia, 57, 353-8 (1986).

19- M. Marlier, G. A. Dardenne and J. Casimir, Phytochemistry, 11, 2597 (1972).

20- M. Marlier, G. Dardenne and J. Casimir, Phytochemistry, 18, 479 (1979).

21- E. L. Core, Plant Taxonomy Englewood Cliffs, N.J. Prentice-Hall, Inc, 267, 334-5 (1955).

22- J. Hutchinson, "The Genera of the Flowering Plants (Angiospermae)", Vol. I , Oxoford, At the Clarendon Press, p. 297 (1964).

23- Katherine Esau, "Plant Anatomy", 2nd Ed. John Wiley and Sons, Inc., New York, London, Sydney, Toppan Company, Ltd., Tokyo, Japan, p. 186 (1965).

24- C. R. Metcalf and L. Chalk, "Anatomy of the Dicotyledons", Vol. I, Oxford University Press, Ely House, London W.I., p. 481 (1972). 